\title{
Genetic Gain in Wheat Grain Yield and Nitrogen Use Efficiency at Different Nitrogen Levels in an Irrigated Hot Environment
}

\author{
Izzat Sidahmed Ali Tahir (D), ${ }^{1}$ Elfadil Mohamed Elyayeb Elbashier, ${ }^{1}$ \\ Mohamed Ahmed Salih Ibrahim, ${ }^{1}$ Abu Sefyan Ibrahim Saad, ${ }^{1}$ and Osman Suliman Abdalla ${ }^{2}$ \\ ${ }^{1}$ Agricultural Research Corporation, P. O. Box 126 Wad Medani, Sudan \\ ${ }^{2}$ Arab Organization for Agricultural Development (AOAD), Khartoum, Sudan
}

Correspondence should be addressed to Izzat Sidahmed Ali Tahir; izzatahir@yahoo.com

Received 11 December 2019; Revised 28 February 2020; Accepted 12 March 2020; Published 28 April 2020

Academic Editor: Cristina Patanè

Copyright (C) 2020 Izzat Sidahmed Ali Tahir et al. This is an open access article distributed under the Creative Commons Attribution License, which permits unrestricted use, distribution, and reproduction in any medium, provided the original work is properly cited.

\begin{abstract}
Improved nitrogen use-efficient cultivars could be the most economically beneficial and environmentally friendly approach to reduce pollution associated with excessive $\mathrm{N}$ fertilization. The performance and genetic gain in grain yield and nitrogen use efficiency (NUE) of a historical set of 12 bread wheat cultivars released for a heat-stressed environment were investigated at four $\mathrm{N}$ levels $\left(0\left(\mathrm{~N}_{0}\right), 43\left(\mathrm{~N}_{43}\right), 86\left(\mathrm{~N}_{86}\right)\right.$, and $\left.129\left(\mathrm{~N}_{129}\right) \mathrm{kg} / \mathrm{ha}\right)$ for two seasons. Averaged across seasons, increasing $\mathrm{N}$ level from $\mathrm{N}_{0}$ to $\mathrm{N}_{43}, \mathrm{~N}_{86}$, and $\mathrm{N}_{129}$ resulted in yield increases ranging from $4-45 \%, 13-69 \%$, and $34-87 \%$ at $\mathrm{N}_{43}, \mathrm{~N}_{86}$, and $\mathrm{N}_{129}$, respectively. These yield increases were associated with increases in biomass $(r=0.86, P<0.01)$. Regressing grain yield of cultivars released during 1960 to 2006 against the year of release showed no trend at $\mathrm{N}_{0}$ and positive nonsignificant trends at $\mathrm{N}_{43}$; however, significant positive trends were found at $\mathrm{N}_{86}$ and $\mathrm{N}_{129}$ with genetic gain rates of 12.65 and $15.76 \mathrm{~kg} \mathrm{ha}^{-1}$ year $^{-1}$, respectively. This gain was associated with progresses in harvest index (HI) at $\mathrm{N}_{43}, \mathrm{~N}_{86}$, and $\mathrm{N}_{129}$ but not at $\mathrm{N}_{0}$. On the other hand, during the period from 1960 to 1990, the genetic gain in grain yield at $\mathrm{N}_{86}$ was $24.5 \mathrm{~kg} \mathrm{ha}^{-1}$ year $^{-1}$. Regressing NUE against the year of release showed significant linear trends at $\mathrm{N}_{86}$ and $\mathrm{N}_{129}\left(R^{2}=0.511\right.$ and $R^{2}=0.477$, respectively), but not at $\mathrm{N}_{43}$. The results indicate that breeders improved grain yield and NUE over 46 years under the heat-stressed environment of Sudan although the rate of increase in yield has been slowed down in recent years. Further improvement in NUE might require broadening the genetic diversity and simultaneous evaluation at low and high $\mathrm{N}$ levels.
\end{abstract}

\section{Introduction}

The recent worldwide interest to avoid environmental hazards associated with $\mathrm{N}$ losses and to reduce the high cost of production is bringing more emphasis in breeding cultivars possessing improved NUE while maintaining an acceptable yield [1-5]. Sustainable agricultural production requires efficient management of $\mathrm{N}$ through agronomic practice and the use of appropriate germplasm that are optimized for traits related to $\mathrm{N}$ use efficiency rather than yield alone [6]. In addition, field management tools such as drought priming have been suggested to enhance grain yield and nitrogen use efficiency under multiple abiotic stresses in a future drier and warmer climate [7].
Thousands of modern semidwarf wheat (Triticum aestivum L.) cultivars with high-yielding potential, highly responsive to nutrients, especially $\mathrm{N}$, have been released for use in both favorable and marginal environments since the "Green Revolution" era in 1960s. It is generally thought that these modern high-yielding cultivars demand high $\mathrm{N}$ level to maximize their yield $[8,9]$. However, it would be economically and environmentally beneficial to have high-yielding genotype that could attain maximum yield at low $\mathrm{N}$ input especially in the light of global climate changes [10]. It has been reported that some modern cultivars outyielded both old tall and earlier semidwarf cultivars at all nitrogen levels [11, 12].

Considerable genetic diversity has been reported in wheat for nitrogen uptake and utilization efficiencies 
$[10,11,13,14]$. However, further improvements may require exploitation of a wider germplasm pool through utilization of land races and ancestral germplasm [6]. Wheat genotypes with high harvest index and low forage yield showed low $\mathrm{N}$ loss and increased $\mathrm{N}$ use efficiency [15]. For further genetic improvement, maximizing $\mathrm{N}$ capture, partitioning and remobilization of $\mathrm{N}$ to the grain, and yield per se could be targeted [6].

Nitrogen use efficiency is genetically controlled; however, some environmental factors such as drought and heat stresses could modify the genetic effects. High temperature during grain filling stage is reported to reduce $\mathrm{N}$ remobilization from the stems to the grains of wheat [16]. However, $\mathrm{N}$ fertilization under heat stress was found to increase biomass production and canopy temperature depression $[17,18]$. These traits are known to be important for wheat productivity under heat stress conditions [19-22]. So far, differential genotypic response to different $\mathrm{N}$ fertilization levels has been rarely addressed under dry, hot irrigated environments. On the other hand, genetic progress in grain yield and NUE have been reported at different environmental conditions $[12,23,24]$. However, despite the fact that genetic gain in grain yield of $25.6 \mathrm{~kg} \mathrm{ha}^{-1}$ year $^{-1}$ has been reported at the heat-stressed environment of Sudan using the recommended $\mathrm{N}$ dose [25], very little is known about the genetic progress made in wheat grain yield and $\mathrm{N}$ use efficiency under different $\mathrm{N}$ levels in such environments. Periodic and frequent evaluation of the genotypes and the breeding methodologies followed is essential for attaining progressive genetic gain in grain yield and NUE and identifying traits that might need more emphasis by breeders especially in the light of the changing climate. Moreover, the environment where this study has been conducted is expected to represent the future environment of several areas when the ensuing climate change is considered. Hence, valuable information could be provided for the global wheat community that could provide roadmap for the future crop improvement. This study investigated the genotypic variation in the performance and the genetic progress in grain yield and $\mathrm{N}$ use efficiency in response to four $\mathrm{N}$ levels of a historical set of bread wheat cultivars released for a hot irrigated environment.

\section{Materials and Methods}

Twelve bread wheat genotypes were used in this study to represent a historical set of cultivars released during 1960 to 2006 for the dry, hot irrigated environment of Sudan. The two eldest cultivars (Beladi and Giza 155) are tall (full stature), whereas the rest have semidwarf stature. The cultivars were grown in a field experiment conducted at the Gezira Research Station Farm (GRSF), Wad Medani $\left(14^{\circ} 44^{\prime} \mathrm{N} ; 33^{\circ} 29^{\prime} \mathrm{E} ; 411 \mathrm{~m}\right.$ asl), Sudan, for two seasons $2006 /$ 07 and 2007/08. At GRSF, the soil is categorized as fine, heavy cracking montmorillonitic, isohyperthermic soil with $\mathrm{pH}$ of 8.0-8.5 and the rooting depth is up to about $0.4 \mathrm{~m}$. The soil is poor in organic matter $(0.3 \%)$, deficient in total nitrogen $(0.03-0.05 \%)$, and low in available phosphorus (4-5 ppm; Olsen extractable P).
The 12 cultivars were evaluated under four nitrogen levels; $0 \mathrm{~kg} \mathrm{~N} / \mathrm{ha}\left(\mathrm{N}_{0}\right), 43 \mathrm{~kg} \mathrm{~N} / \mathrm{ha}\left(\mathrm{N}_{43}\right), 86 \mathrm{~kg} \mathrm{~N} / \mathrm{ha}\left(\mathrm{N}_{86}\right)$, and $129 \mathrm{~kg} \mathrm{~N} / \mathrm{ha}\left(\mathrm{N}_{129}\right)$ split-applied in the form of urea at three-leaf and tillering stages. The recommended dose of phosphorus fertilizer in the form of triple super phosphate at the rate of $43 \mathrm{~kg} \mathrm{P}_{2} \mathrm{O}_{5} /$ ha was applied by furrow placement prior to sowing. The daily maximum and minimum temperatures have been provided from a meteorological station located within the experimental sites during the two cropping seasons (2006/07 and 2007/08).

Seeds were treated with Gaucho (imidacloprid 35\% WP) for the control of pests mainly termites and aphids. Sowing was done mechanically in plots consisting of eight rows, $5 \mathrm{~m}$ long and $0.2 \mathrm{~m}$ apart in both seasons, using a seed rate of $120 \mathrm{~kg} \mathrm{ha}^{-1}$. Sowing was done during the $3^{\text {rd }}$ week of November in both seasons. To avoid any water stress, the experiment was irrigated frequently (every 10-12 days) and kept free from weeds by manual weeding at least twice. The experiment was arranged in a randomized complete block design with three replications in both seasons. It is noteworthy that the experimental site was free from major wheat diseases and no serious lodging was reported that could have affected the grain yield.

Excluding the two border rows, a net area of $2.4 \mathrm{~m}^{2}(4$ rows by $3 \mathrm{~m}$ ) was harvested manually from the ground level in the first season, whereas the area harvested in the second season was $4.8 \mathrm{~m}^{2}$ ( 6 rows by $4 \mathrm{~m}$ ). The harvested material was bundled and left to dry, then weighed, and threshed, and the grain was weighed again to give biomass and grain yield. Harvest index was calculated as the ratio of grain yield to biomass weight.

Representative plant samples were taken at harvest to determine the nitrogen contents of the aboveground portions. Samples were oven-dried to constant weight before grinding. Nitrogen was determined by semi micro-Kjeldhal procedure of [26]. Nitrogen uptake in grains (NUTG) and nitrogen uptake in straw (NUTS) were calculated by the multiplication of the $\mathrm{N}$ concentration in both fractions by their corresponding dry weights $(\mathrm{kg} / \mathrm{ha})$.

Ladha et al. [27] defined 18 different ways to calculate the nitrogen use efficiency. In this study, only three terms of NUE were used, namely:

$\mathrm{NUE}=\mathrm{kg}$ grain per $\mathrm{kg}$ of available $\mathrm{N}$ from soil and fertilizer.

$\mathrm{N}$ utilization efficiency $(\mathrm{NUTE})=\mathrm{kg}$ grains divided by above ground plant $\mathrm{N}$.

$\mathrm{N}$ harvest index $(\mathrm{NHI})=$ proportion of grain $\mathrm{N}$ from the above ground plant $\mathrm{N}$ (above ground plant $\mathrm{N}$ was the summation of grain and straw $\mathrm{N}$ uptake).

Data were subjected to analyses of variance for each season separately and then combined analysis was carried out after the error mean squares were tested for homogeneity. Genotype and $\mathrm{N}$ level were considered as fixed factors, whereas season and replication nested within each $\mathrm{N}$ level were treated as random factors. Only the combined data for both seasons are presented since season $\times \mathrm{N}$ level $\times$ genotype was not significant for most of the measured traits. Standard ANOVA was performed for the NUE traits. Simple correlation coefficients were calculated among different traits 
using genotype means across $\mathrm{N}$ levels $(n=48)$. Regression analysis was used to measure the relationship of the year of release with the grain yield and NUE. Time elapsed from the year of release was regarded as a quantitative variable to estimate the progress in genetic grain for grain yield and NUE. Eleven cultivars (excluding Tagana) were used in this analysis. Rates of increase in grain yield and NUE were estimated from the slope of the regression line.

\section{Results}

The weekly maximum and minimum temperatures at GRSF during the two cropping seasons (2006/07 and 2007/08) as well as a 30-year average (LTA) during 1980-2010 are shown in Figure 1. During most parts of the crop vegetative stage in the second season, the maximum and minimum temperatures were higher compared to the $1^{\text {st }}$ season and the LTA. However, temperatures of both seasons became almost similar from midseason onward. During the growth cycle, temperatures above $35^{\circ} \mathrm{C}$ were experienced for more than 20 days during both seasons as well as the LTA.

3.1. Genotypic Variation. Significant differences were found between the $\mathrm{N}$ levels and genotypes for all studied traits. Addition of $\mathrm{N}$ increased biomass and grain yield of all genotypes. However, the magnitude of the response varied among the genotypes.

Mean biomass of the 12 genotypes increased from $5423 \mathrm{~kg} / \mathrm{ha}$ at $\mathrm{N}_{0}$ to $6750 \mathrm{~kg} / \mathrm{ha}$ at $\mathrm{N}_{43}, 8023 \mathrm{~kg} / \mathrm{ha}$ at $\mathrm{N}_{86}$, and $8924 \mathrm{~kg} /$ ha at $\mathrm{N}_{129}$ (Table 1 ). At $\mathrm{N}_{43}$, Argine showed only $1 \%$ increase in biomass compared to that at $\mathrm{N}_{0}$, whereas Wadi Elneel showed $43 \%$ increase. The percent increase in biomass of Condor was 27, whereas that of Wadi Elneel was 65 at $\mathrm{N}_{86}$. Khalifa and Nesser were the two contrasting genotypes in the percent increase of biomass at $\mathrm{N}_{129}$ compared to $\mathrm{N}_{0}$.

Significant differences in grain yield among $\mathrm{N}$ levels and genotypes were found (Table 2). Across all genotypes, increasing $\mathrm{N}$ level from $\mathrm{N}_{0}$ to $\mathrm{N}_{43}, \mathrm{~N}_{86}$, and $\mathrm{N}_{129}$ resulted in increases in grain yield by 24,44 , and $55 \%$, respectively. Averaged across $\mathrm{N}$ levels, increasing $\mathrm{N}$ level from $\mathrm{N}_{0}$ to $\mathrm{N}_{43}$ increased grain yield with ranges from $4 \%$ in Argine to $45 \%$ in Wadi Elneel. Similarly, increasing $\mathrm{N}$ level from $\mathrm{N}_{0}$ to $\mathrm{N}_{86}$ and $\mathrm{N}_{129}$ resulted in grain yield increases ranging from $13 \%$ in Condor to $69 \%$ in Nesser at $\mathrm{N}_{86}$ and from $34 \%$ in Debeira to $87 \%$ in Khalifa at $\mathrm{N}_{129}$. Genotypes Khalifa, Imam, Bohaine, and Elnielain showed continuous increases in grain yield with application of more $\mathrm{N}$. In contrast, addition of more $\mathrm{N}$ above $\mathrm{N}_{86}$ did not improve the grain yield of $\mathrm{Wadi}$ Elneel, Tagana, and Nesser. Most of the increase in grain yield of the later genotypes resulted from the addition of $43 \mathrm{~kg} \mathrm{ha}^{-1}$.

Genotypes showed mixed reactions in response of harvest index (HI) to increasing $\mathrm{N}$ levels. For example, the $\mathrm{HI}$ of Nesser increased by 14,15 , and $10 \%$ at $\mathrm{N}_{43}, \mathrm{~N}_{86}$, and $\mathrm{N}_{129}$, respectively, compared to $\mathrm{N}_{0}$, whereas Beladi, Giza 155, Condor, and Debeira showed different decreasing trends with addition of more $\mathrm{N}$ (Table 3 ).
Significant differences in NUE among N levels, genotypes, and their interaction were found (Table 4). Across all genotypes, increasing $\mathrm{N}$ level resulted in decreases of NUE from $58.7 \mathrm{~kg}$ grain $/ \mathrm{kg} \mathrm{N}$ applied at $\mathrm{N}_{43}$ to $36.1 \mathrm{~kg}$ grain $/ \mathrm{kg} \mathrm{N}$ applied at $\mathrm{N}_{86}$ and $27.0 \mathrm{~kg}$ grain $/ \mathrm{kg} \mathrm{N}$ applied at $\mathrm{N}_{129}$. Averaged across $\mathrm{N}$ levels, NUE of the cultivars ranged from $33.8 \mathrm{~kg}$ grain $/ \mathrm{kg} \mathrm{N}$ applied in the old cultivar Beladi to $43.8 \mathrm{~kg}$ grain $/ \mathrm{kg} \mathrm{N}$ applied in Elnielain.

Table 5 shows the nitrogen uptake in the straw and grains. Significant $(P<0.001)$ genotypic variations in straw $\mathrm{N}$ uptake were detected. Across all nitrogen levels, the highest $\mathrm{N}$ uptake in straw was recorded by Beladi, Giza 155, and Tagana. On the other hand, Bohaine, Nesser, and Condor recorded the lowest biomass $\mathrm{N}$ uptake (Table 5).

The grain $\mathrm{N}$ uptake of the 12 wheat genotypes significantly increased by addition of $\mathrm{N}$. Across all nitrogen levels applied, significant variation among tested genotypes was found. The old cultivar (Beladi), Tanana, and Debeira recorded the lowest $\mathrm{N}$ uptake, whereas Bohaine and Argine recorded the highest $\mathrm{N}$ uptake (Table 5).

Averaged across all genotypes, the proportion of grain $\mathrm{N}$ from the total above ground plant nitrogen (nitrogen harvest index, NHI), also known as translocation coefficient and reutilization efficiency, varied significantly among genotypes. The $\mathrm{NHI}$ at $\mathrm{N}_{129}$ was significantly higher than that at other N levels. Across all N levels, Bohaine, Argine, and Condor showed significantly higher nitrogen harvest index, whereas Debeira, Beladi, and Tagana recorded the lowest (Table 5).

The grain yield produced from a unit of above ground plant $\mathrm{N}$ uptake (i.e., nitrogen utilization efficiency, NUTE) was significantly reduced with each increase in $\mathrm{N}$ rate. Significant variation among the 12 wheat genotypes in NUTE was also found. Across all nitrogen levels, NUTE was highest in Debeira (47.4 kg grain $/ \mathrm{kg} \mathrm{N}$ taken up) followed by Wadi Elneel, Khalifa, and Elnielain (Table 5).

\subsection{Genetic Gain in Grain Yield under Different Nitrogen} Levels. The grain yields under different $\mathrm{N}$ levels as well as the mean grain yield across all $\mathrm{N}$ levels were linearly regressed against the years elapsed since the release of the cultivars (1960 was considered as the year of Beladi release). Regressing the grain yield at $\mathrm{N}_{0}$ against the year of release showed no trend $\left(R^{2}=0.003, P=0.957\right)$ (Figure 2). A positive nonsignificant trend was noticed when the year of release was regressed against the grain yield at $\mathrm{N}_{43}\left(R^{2}=0.17\right.$, $P=0.208)$. On the other hand, positive and significant relations were found when the grain yield at $\mathrm{N}_{86}$ and $\mathrm{N}_{129}$ was plotted against the year of release $\left(R^{2}=0.511, P=0.013\right.$ and $R^{2}=0.477, P=0.019$, respectively). Based on the regression of grain yield at $\mathrm{N}_{86}$ in the two seasons versus the year of release, the grain yield has increased from $2614.3 \mathrm{~kg} \mathrm{ha}^{-1}$ in 1960 to $3196.3 \mathrm{~kg} \mathrm{ha}^{-1}$ in 2006 with an annual rate of $12.65 \mathrm{~kg} \mathrm{ha}^{-1}$ year $^{-1}\left(0.48 \%\right.$ year $^{-1}$ on the relative basis). Similarly, grain yield at $\mathrm{N}_{129}$ increased from $2804.8 \mathrm{~kg} \mathrm{ha}^{-1}$ in 1960 to $3529.6 \mathrm{~kg} \mathrm{ha}^{-1}$ in 2006 with an annual rate of $15.76 \mathrm{~kg} \mathrm{ha}^{-1}$ year $^{-1}\left(0.56 \%\right.$ year $^{-1}$ on the relative basis $)$. Likewise, regressing mean grain yield across all $\mathrm{N}$ levels in 


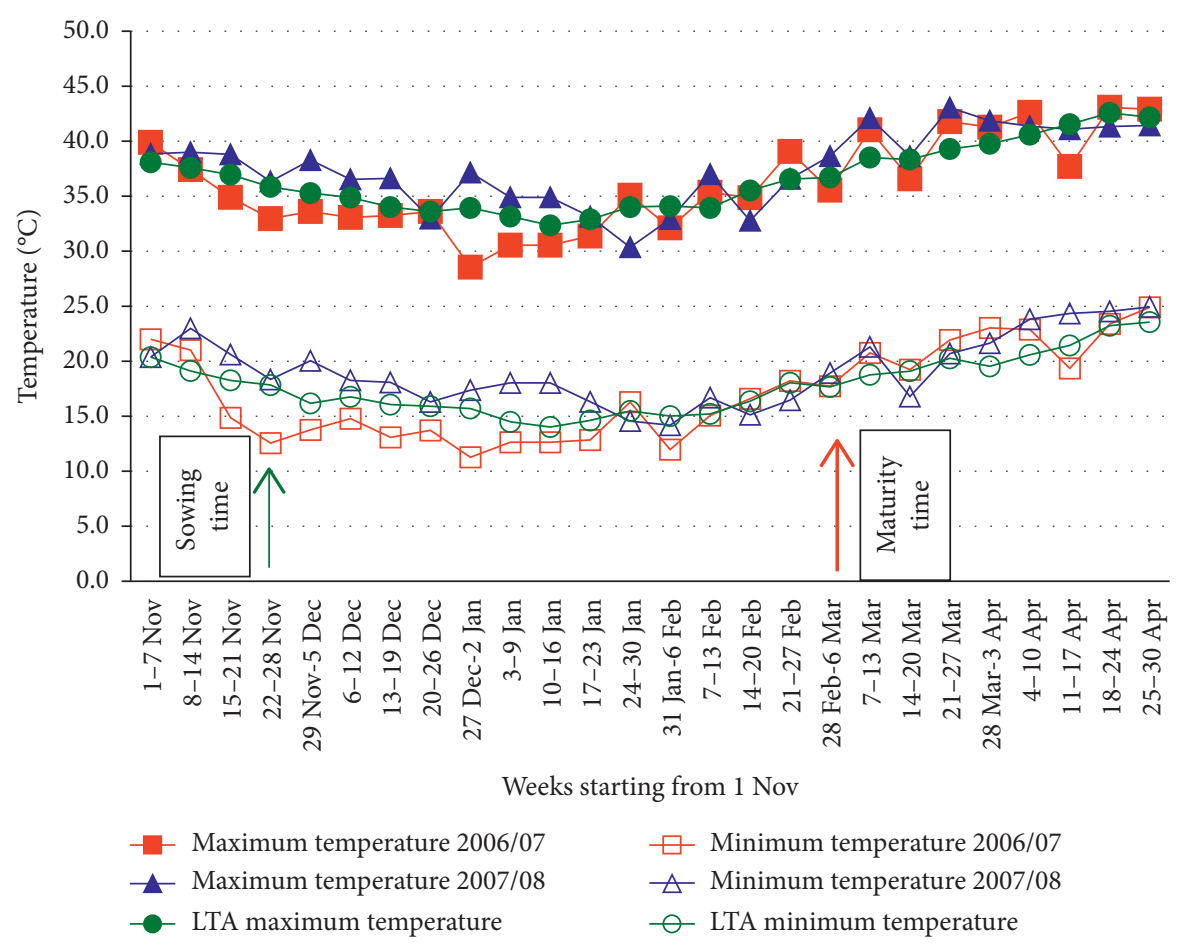

FIGURE 1: Weekly maximum and minimum temperature at Gezira Research Station during two cropping seasons (2006/07 and 2007/08) together with a 30-year average (LTA) temperature (1980-2010).

TABLE 1: Mean biomass (kg/ha) of 12 bread wheat genotypes grown for two seasons under four N levels at Gezira Research Station Farm, Wad Medani, Sudan.

\begin{tabular}{lcccc}
\hline Genotype $^{\dagger}$ & \multicolumn{4}{c}{ Biomass (kg/ha) } \\
& $\mathrm{N}_{0}$ & $\mathrm{~N}_{43}$ & $\mathrm{~N}_{86}$ & $\mathrm{~N}_{129}$ \\
\hline Beladi 60 & 6005 & $6981(16)$ & $8447(41)$ & $9533(59)$ \\
Giza 155 71 & 5474 & $7079(29)$ & $8276(51)$ & $9679(77)$ \\
Condor 78 & 5128 & $6206(21)$ & $6519(27)$ & $8661(69)$ \\
Debeira 82 & 5853 & $7188(23)$ & $8101(38)$ & $8907(52)$ \\
Wadi Elneel 87 & 4982 & $7148(43)$ & $8203(65)$ & $8522(71)$ \\
Elnielain 90 & 5854 & $6934(18)$ & $8590(47)$ & $9215(57)$ \\
Nesser 96 & 5089 & $6454(27)$ & $7465(47)$ & $7363(45)$ \\
Argine 96 & 5547 & $5575(1)$ & $8385(51)$ & $9081(64)$ \\
Imam 00 & 5433 & $7007(29)$ & $7924(46)$ & $9187(69)$ \\
Tagana 04 & 5332 & $7253(36)$ & $8657(62)$ & $9439(77)$ \\
Khalifa 04 & 4908 & $6729(37)$ & $7923(61)$ & $9402(92)$ \\
Bohaine 06 & 5470 & $6444(18)$ & $7786(42)$ & $8104(48)$ \\
Mean & $\mathbf{5 4 2 3}$ & $\mathbf{6 7 5 0 ( 2 5 )}$ & $\mathbf{8 0 2 3}(\mathbf{4 8})$ & $\mathbf{8 9 2 4}(\mathbf{6 5})$ \\
SE \pm for: & & & & \\
$\quad \mathrm{N}$ level (N) & & $144.5^{* * *}$ & & \\
$\quad$ Genotype $(G)$ & & $120.9^{* * *}$ & & \\
$\quad \mathrm{~N} \times G$ & & $241.8^{*}$ & & \\
\hline
\end{tabular}

Number in parentheses is the percent difference relative to $\mathrm{N}_{0} .{ }^{*}$ Significant at $P=0.05 ;{ }^{* * *}$ significant at $P=0.001$. ${ }^{\dagger}$ The numerical suffix (in bold) to the genotype name refers to the year of its release in Sudan.

the two seasons versus the year of release showed that the grain yield has increased from $2473.3 \mathrm{~kg} \mathrm{ha}^{-1}$ in 1960 to $2870.2 \mathrm{~kg} \mathrm{ha}^{-1}$ in 2006 with an annual rate of $8.63 \mathrm{~kg} \mathrm{ha}^{-1}$ year $^{-1}$ ( $0.35 \%$ year $^{-1}$ on the relative basis). The genetic gain in grain yield is associated with increases in harvest index at $\mathrm{N}_{43}, \mathrm{~N}_{86}$, and $\mathrm{N}_{129}$ but not at $\mathrm{N}_{0}$. The $\mathrm{HI}$
TABLE 2: Mean grain yield ( $\mathrm{kg} / \mathrm{ha})$ of 12 bread wheat genotypes grown for two seasons under four $\mathrm{N}$ levels at Gezira Research Station Farm, Wad Medani, Sudan.

\begin{tabular}{lcccc}
\hline \multirow{2}{*}{ Genotype } & \multicolumn{4}{c}{ Grain yield (kg/ha) } \\
& $\mathrm{N}_{0}$ & $\mathrm{~N}_{43}$ & $\mathrm{~N}_{86}$ & $\mathrm{~N}_{129}$ \\
\hline Beladi 60 & 1923 & $2178(13)$ & $2558(33)$ & $2716(41)$ \\
Giza 155 71 & 2000 & $2445(22)$ & $2722(36)$ & $2994(50)$ \\
Condor 78 & 2272 & $2558(13)$ & $2561(13)$ & $3188(40)$ \\
Debeira 82 & 2323 & $2668(15)$ & $3023(30)$ & $3104(34)$ \\
Wadi Elneel 87 & 1988 & $2874(45)$ & $3145(58)$ & $3167(59)$ \\
Elnielain 90 & 2306 & $2730(18)$ & $3314(44)$ & $3783(64)$ \\
Nesser 96 & 1835 & $2603(42)$ & $3100(69)$ & $2889(57)$ \\
Argine 96 & 2201 & $2283(4)$ & $3166(44)$ & $3364(53)$ \\
Imam 00 & 2011 & $2510(25)$ & $2887(44)$ & $3352(67)$ \\
Tagana 04 & 1952 & $2715(39)$ & $2979(53)$ & $2826(45)$ \\
Khalifa 04 & 1985 & $2760(39)$ & $3101(56)$ & $3704(87)$ \\
Bohaine 06 & 2129 & $2525(19)$ & $3103(46)$ & $3477(63)$ \\
Mean & $\mathbf{2 0 7 7}$ & $\mathbf{2 5 7 1 ( 2 4 )}$ & $\mathbf{2 9 7 2 ( 4 4 )}$ & $\mathbf{3 2 1 4}(\mathbf{5 5})$ \\
SE \pm for: & & & & \\
$\quad \mathrm{N}$ level (N) & & $41.75^{* * *}$ & & \\
$\quad$ Genotype $(G)$ & & $61.8^{* * *}$ & & \\
$\quad \mathrm{~N} \times G$ & & $174.7^{* *}$ & & \\
\hline
\end{tabular}

Number in parentheses is the percent difference relative to $\mathrm{N}_{0} \cdot{ }^{* *}$ Significant at $P=0.01{ }^{* * *}$ significant at $P=0.001$.

increased by $0.16 \%$ year $^{-1}\left(R^{2}=0.452, P<0.01\right), 0.17 \%$ year $^{-1}\left(R^{2}=0.573, P \leq 0.01\right)$, and $0.25 \%$ year $^{-1}\left(R^{2}=0.731\right.$, $P \leq 0.01$ ) at $\mathrm{N}_{43}, \mathrm{~N}_{86}$, and $\mathrm{N}_{129}$, respectively (Figure 3).

On the other hand, when the period from 1960 to 1990 was considered, the genetic gains in grain yield at different $\mathrm{N}$ levels were higher. For instant, the genetic gain for the mean grain yield across all $\mathrm{N}$ levels was estimated to be 
TABle 3: Mean harvest index (\%) of 12 bread wheat genotypes grown for two seasons under four $\mathrm{N}$ levels at Gezira Research Station Farm, Wad Medani, Sudan.

\begin{tabular}{lcccc}
\hline \multirow{2}{*}{ Genotype } & \multicolumn{4}{c}{ Harvest index (\%) } \\
& $\mathrm{N}_{0}$ & $\mathrm{~N}_{43}$ & $\mathrm{~N}_{86}$ & $\mathrm{~N}_{129}$ \\
\hline Beladi 60 & 31.7 & $31.3(-1)$ & $30.3(-4)$ & $28.4(-10)$ \\
Giza 155 71 & 36.7 & $34.4(-6)$ & $32.8(-11)$ & $30.8(-16)$ \\
Condor 78 & 44.3 & $41.4(-7)$ & $39.7(-11)$ & $37.5(-15)$ \\
Debeira 82 & 39.8 & $37.1(-7)$ & $37.2(-7)$ & $34.9(-12)$ \\
Wadi Elneel 87 & 40.1 & $39.8(-1)$ & $38.3(-4)$ & $37.0(-8)$ \\
Elnielain 90 & 39.6 & $39.1(-1)$ & $38.3(-3)$ & $41.4(5)$ \\
Nesser 96 & 35.9 & $40.7(14)$ & $41.2(15)$ & $39.4(10)$ \\
Argine 96 & 39.6 & $41.2(4)$ & $37.8(-5)$ & $37.6(-5)$ \\
Imam 00 & 36.8 & $35.5(-3)$ & $36.5(-1)$ & $36.5(-1)$ \\
Tagana 04 & 36.7 & $37.7(3)$ & $34.0(-7)$ & $30.3(-17)$ \\
Khalifa 04 & 40.9 & $41.6(2)$ & $38.9(-5)$ & $39.4(-4)$ \\
Bohaine 06 & 39.3 & $39.6(1)$ & $39.9(2)$ & $42.9(9)$ \\
Mean & $\mathbf{3 8 . 4}$ & $\mathbf{3 8 . 3 ( 0 )}$ & $\mathbf{3 7 . 1}(-3)$ & $\mathbf{3 6 . 3}(-\mathbf{5})$ \\
SE \pm for: & & & & \\
$\quad \mathrm{N}$ level (N) & & $0.59^{*}$ & & \\
$\quad$ Genotype $(G)$ & & $0.74^{* *}$ & & \\
$\quad \mathrm{~N} \times G$ & & $1.5^{*}$ & & \\
\hline
\end{tabular}

Number in parentheses is the percent difference relative to $\mathrm{N}_{0}$. ${ }^{*}$ Significant at $P=0.05 ;{ }^{* * *}$ significant at $P=0.001$.

$20.67 \mathrm{~kg} \mathrm{ha}^{-1}$ year $^{-1}\left(0.89 \%\right.$ year $^{-1}$ on a relative basis $)$ (Figure 4). At $\mathrm{N}_{86}$ (the recommended $\mathrm{N}$ dose for wheat production in Sudan), the genetic gain was $24.5 \mathrm{~kg} \mathrm{ha}^{-1}$ year $^{-1}$ (1.0\% year ${ }^{-1}$ on a relative basis).

\subsection{Genetic Gain in NUE under Different Nitrogen Levels.} Evaluation of the relationship between NUE of the eleven cultivars (excluding Tagana) under different $\mathrm{N}$ levels and their year of release was done using regression analysis. The NUE under different $\mathrm{N}$ levels as well as the mean NUE was regressed against the year of cultivar release. Regressing NUE at $\mathrm{N}_{43}$ against the year of release revealed nonsignificant positive trend $\left(R^{2}=0.1695, P=0.208\right)$. However, positive and significant relations were found when NUEs were plotted against year of release at $\mathrm{N}_{86}\left(R^{2}=0.511\right.$, $P=0.014)$ and $\mathrm{N}_{129}\left(R^{2}=0.477, P=0.019\right)$ as well as the mean value across the $\mathrm{N}$ levels $\left(R^{2}=0.46, P=0.022\right)$ (Figure 5).

\section{Discussion}

4.1. Genotypic Variation. In this study, a historical set of 12 bread wheat cultivars released for a hot irrigated environment were used to investigate the performance and genetic gain in grain yield and nitrogen use efficiency (NUE) at four $\mathrm{N}$ levels. Addition of $\mathrm{N}$ increased biomass and grain yield of all genotypes. However, the magnitude of the response varied among the genotypes. The mean biomass of the 12 genotypes increased by $60.7 \%$ due to addition of $129 \mathrm{~kg} \mathrm{~N} / \mathrm{ha}$ compared to the control $\left(\mathrm{N}_{0}\right)$. Similarly, increasing $\mathrm{N}$ level from $\mathrm{N}_{0}$ to $\mathrm{N}_{129}$ resulted in increases in grain yield by $55 \%$. The response of some genotypes to addition of $43 \mathrm{~kg} \mathrm{~N} / \mathrm{ha}$ was almost negligible (e.g., Argine), whereas others showed more than $40 \%$ increase in grain yield (Wadi Elneel and
TABle 4: Nitrogen use efficiency (NUE) of 12 bread wheat genotypes grown in season 2006/07 and 2007/08 under different N levels at Gezira Research Station Farm, Wad Medani, Sudan.

\begin{tabular}{lcccc}
\hline Genotype & \multicolumn{4}{c}{ Nitrogen use efficiency } \\
& $\mathrm{N}_{43}$ & $\mathrm{~N}_{86}$ & $\mathrm{~N}_{129}$ & Mean \\
\hline Beladi 60 & 50.7 & 29.7 & 21.1 & 33.8 \\
Giza 155 71 & 56.9 & 31.7 & 23.2 & 37.2 \\
Condor 78 & 59.5 & 29.8 & 24.7 & 38.0 \\
Debeira 82 & 62.0 & 35.2 & 24.1 & 40.4 \\
Wadi Elneel 87 & 66.8 & 36.6 & 24.6 & 42.7 \\
Elnielain 90 & 63.5 & 38.5 & 29.3 & 43.8 \\
Nesser 96 & 60.5 & 36.0 & 22.4 & 39.7 \\
Argine 96 & 53.1 & 36.8 & 26.1 & 38.7 \\
Imam 00 & 58.4 & 33.6 & 26.0 & 39.3 \\
Tagana 04 & 63.1 & 34.6 & 21.9 & 39.9 \\
Khalifa 04 & 64.2 & 36.1 & 28.7 & 43.0 \\
Bohaine 06 & 58.7 & 36.1 & 27.0 & 40.6 \\
Mean & & & & \\
SE \pm for: & & & & \\
N level (N) & & & & \\
$\quad$ Genotype $(G)$ & & & $1.59^{* * * *}$ & \\
$\quad$ N $\times$ G & & & $1.91 *$ & \\
\hline
\end{tabular}

*Significant at $P=0.05 ;{ }^{* * *}$ significant at $P=0.001$.

Nesser). However, addition of more $\mathrm{N}$ increased the grain yield of Argine from $4 \%$ at $\mathrm{N}_{43}$ to $44 \%$ at $\mathrm{N}_{86}$ compared to $\mathrm{N}_{0}$. Similar results for the responsiveness and efficiency of wheat genotypes to the addition of $\mathrm{N}$ have been reported $[10,11,14]$. Increases in biomass and grain yield due to $\mathrm{N}$ fertilization have been reported for old and new genotypes $[14,28]$. However, other reports found that the modern semidwarf cultivars benefitted more from the high $\mathrm{N}$ rate compared to old cultivars $[8,11]$. Our results showed that the grain yield of both old and new cultivars increased. Nevertheless, the percent increases in grain yield of the old cultivars were less than the mean value while those of the new cultivars were always higher than the mean value. It was also noticed that the old cultivars (Beladi and Giza 155) had the highest biomass at $\mathrm{N}_{129}$; however, this was not reflected in their grain yield and thus resulted in decreased HI. One of the new cultivars (Tagana) showed the same trend of increased biomass and decreased $\mathrm{HI}$ at $\mathrm{N}_{129}$ probably because of the tallness of this cultivar compared with the modern ones.

The increases in grain yield under the four $\mathrm{N}$ levels are associated significantly with the counterpart increases in biomass ( $r=0.86, P<0.001$ ). It has been observed that some genotypes efficiently used the increases in biomass under high $\mathrm{N}$ levels for higher grain yield production (e.g., Khalifa and Elnielain), whereas other genotypes were less efficient in utilizing the high biomass for high grain yield (e.g., Giza 155 and Tagana). Biomass accumulation is regarded as one of the key traits for high yield under heat stress $[18,20]$; however, efficient remobilization of these assimilates to grain under heat stress is crucial [16].

Genotypes differentially responded to $\mathrm{N}$ levels in terms of various traits suggesting the existence of wide variation in $\mathrm{N}$ utilization efficiency among the studied genotypes. 
TABLE 5: Straw and grain nitrogen uptake (kg/ha), nitrogen harvest index (NHI), and nitrogen utilization efficiency (NUTE) of 12 bread wheat genotypes grown in season 2008 under four N levels at Gezira Research Station Farm, Wad Medani, Sudan.

\begin{tabular}{|c|c|c|c|c|}
\hline & Straw nitrogen uptake & Grain nitrogen uptake & Nitrogen harvest index & Nitrogen utilization efficiency \\
\hline \multicolumn{5}{|l|}{ Genotype: } \\
\hline Beladi 60 & 26.5 & 34.0 & 0.56 & 36.1 \\
\hline Giza 15571 & 25.3 & 37.0 & 0.59 & 35.2 \\
\hline Condor 78 & 18.8 & 44.6 & 0.70 & 38.8 \\
\hline Debeira 82 & 22.9 & 28.7 & 0.55 & 47.4 \\
\hline Wadi Elneel 87 & 21.2 & 37.9 & 0.63 & 41.8 \\
\hline Elnielain 90 & 20.2 & 40.7 & 0.65 & 41.0 \\
\hline Nesser 96 & 18.7 & 43.6 & 0.68 & 39.4 \\
\hline Argine 96 & 21.3 & 52.1 & 0.70 & 34.1 \\
\hline Imam 00 & 22.3 & 37.7 & 0.62 & 36.6 \\
\hline Tagana 04 & 24.6 & 33.6 & 0.56 & 36.1 \\
\hline Khalifa 04 & 19.7 & 42.5 & 0.68 & 41.3 \\
\hline Bohaine 06 & 17.7 & 51.9 & 0.72 & 37.8 \\
\hline Significance level & $* * *$ & $* * *$ & $* *$ & $*$ \\
\hline $\mathrm{SE} \pm$ & 1.55 & 3.42 & 0.027 & 2.47 \\
\hline \multicolumn{5}{|l|}{ N level: } \\
\hline $\mathrm{N}_{0}$ & 15.8 & 26.8 & 0.63 & - \\
\hline $\mathrm{N}_{43}$ & 19.5 & 31.3 & 0.61 & 43.8 \\
\hline $\mathrm{N}_{86}$ & 24.4 & 42.4 & 0.62 & 38.8 \\
\hline $\mathrm{N}_{129}$ & 26.7 & 60.9 & 0.68 & 33.7 \\
\hline Significance level & $* * *$ & $* * *$ & $* *$ & $* * *$ \\
\hline $\mathrm{SE} \pm$ & 0.77 & 1.71 & 0.013 & 1.24 \\
\hline $\mathrm{CV} \%$ & 20.5 & 23.0 & 12.5 & 19.1 \\
\hline
\end{tabular}

${ }^{*},{ }^{* *},{ }^{* * *}$ Significant at $P=0.05,0.01$, and 0.001 , respectively.

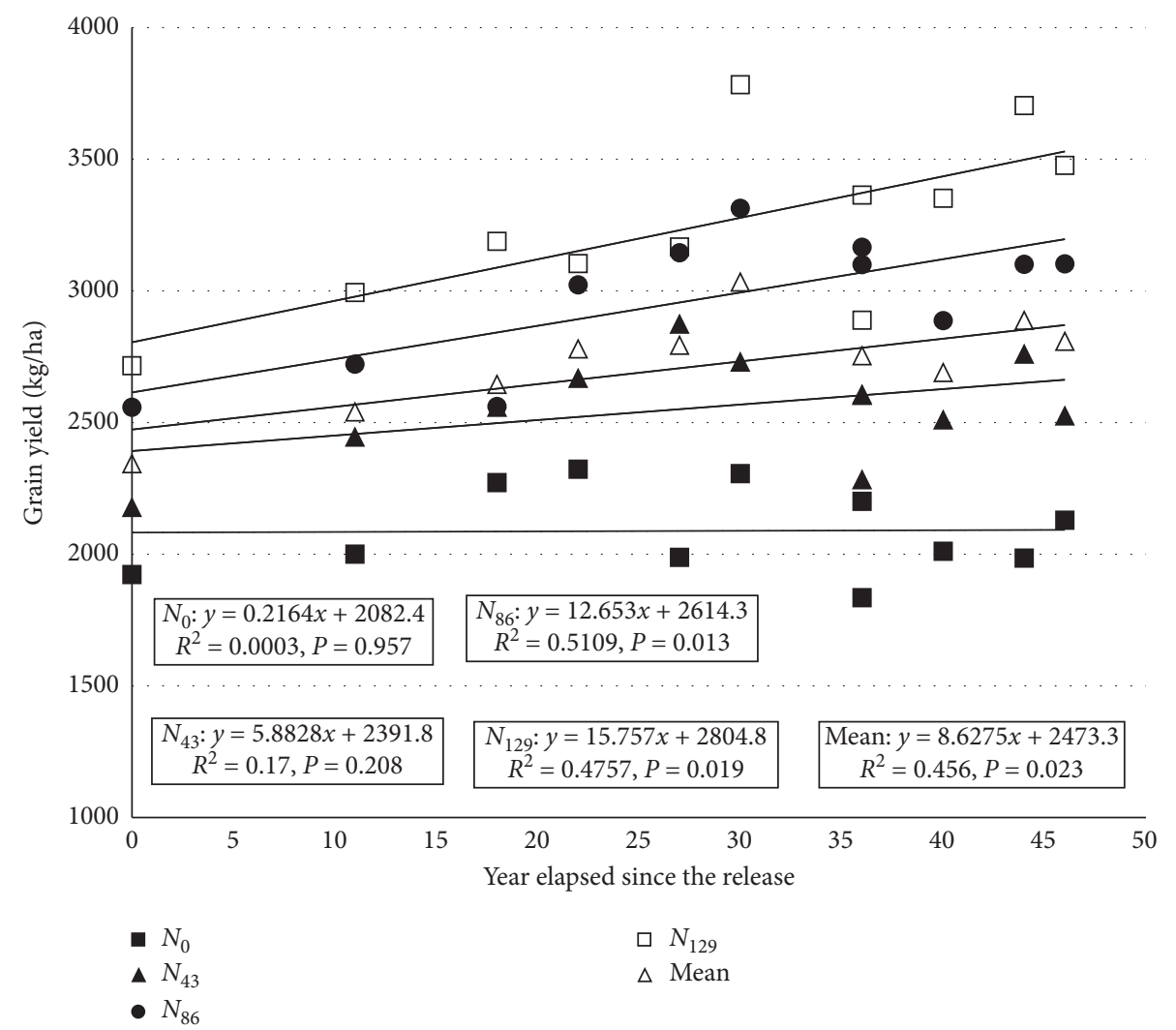

FIGURE 2: Relationship of grain yield $\left(\mathrm{kg} \mathrm{ha}^{-1}\right)$ of 11 bread wheat cultivars released between 1960 and 2006 and grown at four N levels with the time elapsed since their year of release. 


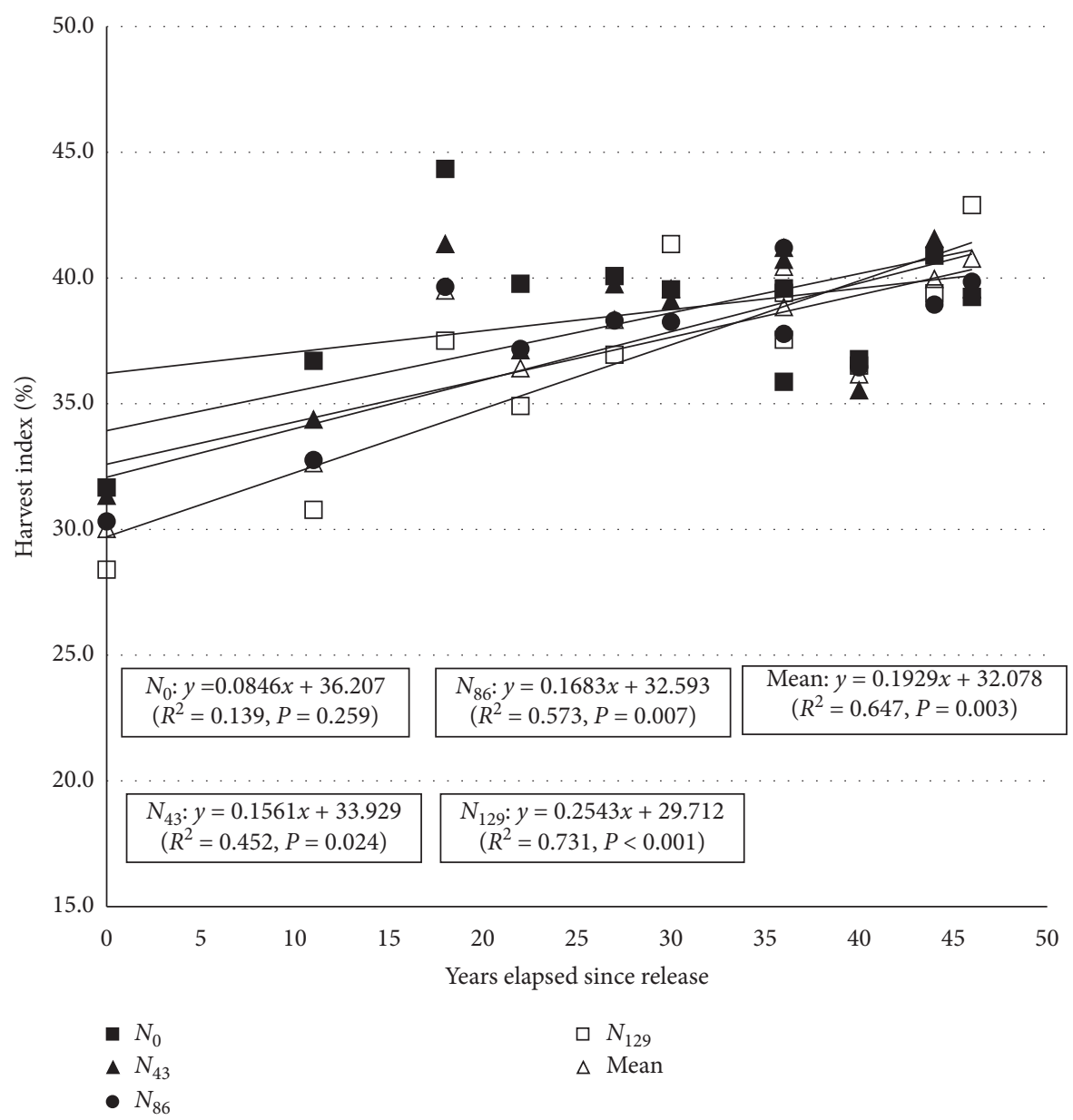

FIGURE 3: Relationship of harvest index (\%) of 11 bread wheat cultivars released between 1960 and 2006 and grown at four N levels with the time elapsed since their year of release.

Genotypic variation observed in this study for $\mathrm{N}$ utilization efficiency and responses supports the thought of including low-input selection environments to maximize selection gains for breeding programs targeting production with low $\mathrm{N}$ input [29]. However, this should not be done at the expense of grain quality which is expected to decrease under low $\mathrm{N}$ input.

The grain $\mathrm{N}$ uptake of the 12 wheat cultivars differed across $\mathrm{N}$ levels. Most of the modern semidwarf cultivars revealed positive and significant increases in grain $\mathrm{N}$ uptake. In contrast to the oldest cultivar used in this study (Beladi), the recent cultivars (Argine and Bohaine) recorded the highest $\mathrm{N}$ uptake. On the other hand, the highest $\mathrm{N}$ uptake in straw across all nitrogen levels was recorded by the tall and old cultivars such as Beladi, Giza 155, and Tagana, whereas the semidwarf cultivars like Bohaine, Nesser, and Condor recorded the lowest biomass $\mathrm{N}$ uptake.

Nitrogen capture would appear to be the key underpinning trait aligned to its use efficiency. The Nitrogen uptake efficiency is defined as the amount of $\mathrm{N}$ taken up by the crop as a function of the available N. At the crop scale, this includes fertilizer, soil N, and atmospherically deposited $\mathrm{N}$ [6]. High yields of high quality grain can only be achieved with high uptakes of $\mathrm{N}$ [1]. It has been observed that while
Bohaine recorded higher grain $\mathrm{N}$ uptake, it showed significantly the lowest straw $\mathrm{N}$ uptake which might be a reflection of high $\mathrm{N}$ translocation capacity of Bohaine compared to other genotypes. Nitrogen and carbohydrate translocation is an important trait because it could serve as an alternative source of assimilates and compensate for the reduced photosynthesis under heat stress conditions [16].

Nitrogen harvest index (NHI) is used also as indicator of genotypic efficiency in nitrogen distribution between vegetative plant parts and the grain; it represents the part of plant nitrogen used for protein synthesis. Grain $\mathrm{N}$ is for a large part derived from canopy $\mathrm{N}$ remobilized during grain filling as the canopy senesces which is more efficient in modern cultivars. Ability of genotype to relocate nitrogen from vegetative parts to grain represents a base for grain protein increase and thus the NHI could be recommended as a selection criterion for nitrogen use efficiency improvement [30]. However, Barraclough et al. [1] reported that the NHI is already high in modern wheat and almost insensitive to $\mathrm{N}$ input. Barraclough et al. [31] reported that the development and use of wheat cultivars with higher NUE can contribute to the reduction of the applied $\mathrm{N}$ amounts without decreasing grain yield. Our results showed that the modern semidwarf cultivars such 


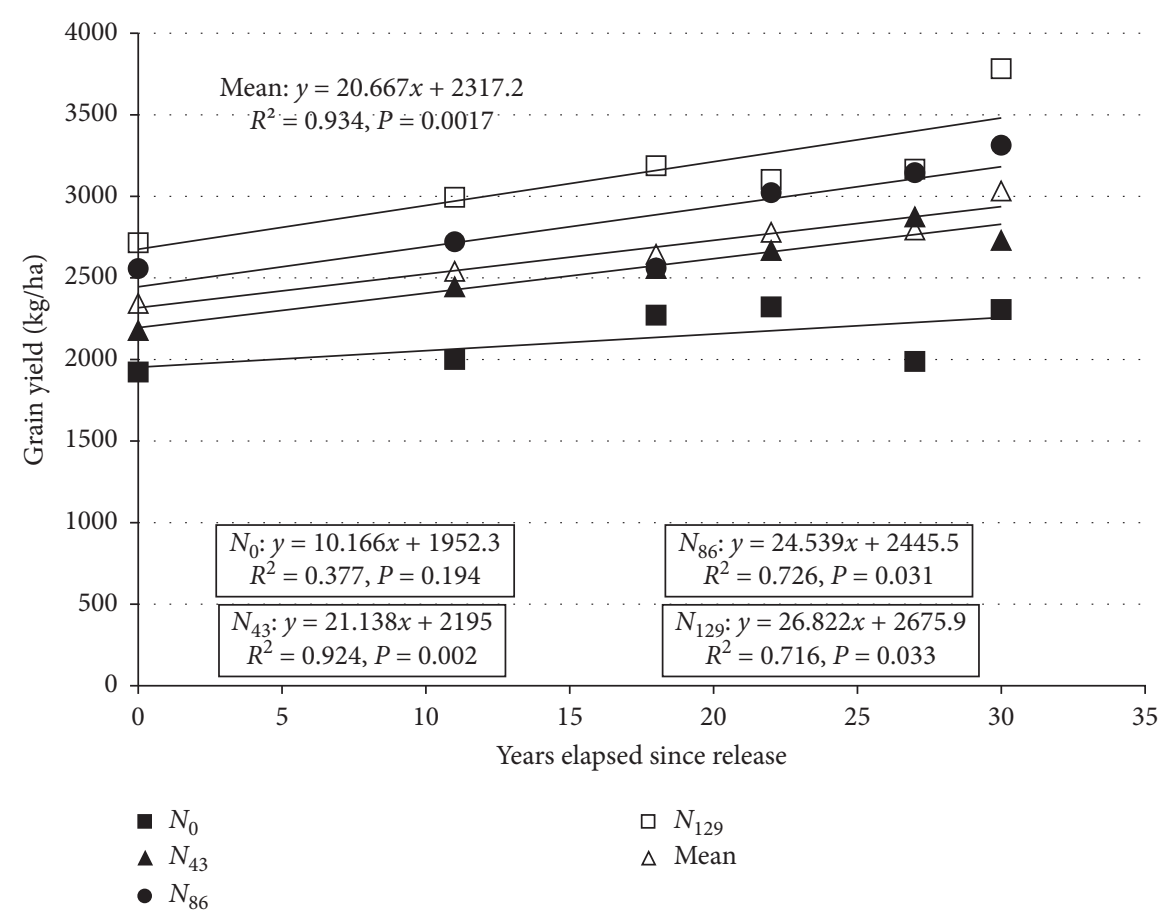

Figure 4: Relationship of grain yield $\left(\mathrm{kg} \mathrm{ha}^{-1}\right)$ of six bread wheat cultivars released between 1960 and 1990 and grown at four N levels with the time elapsed since their year of release.

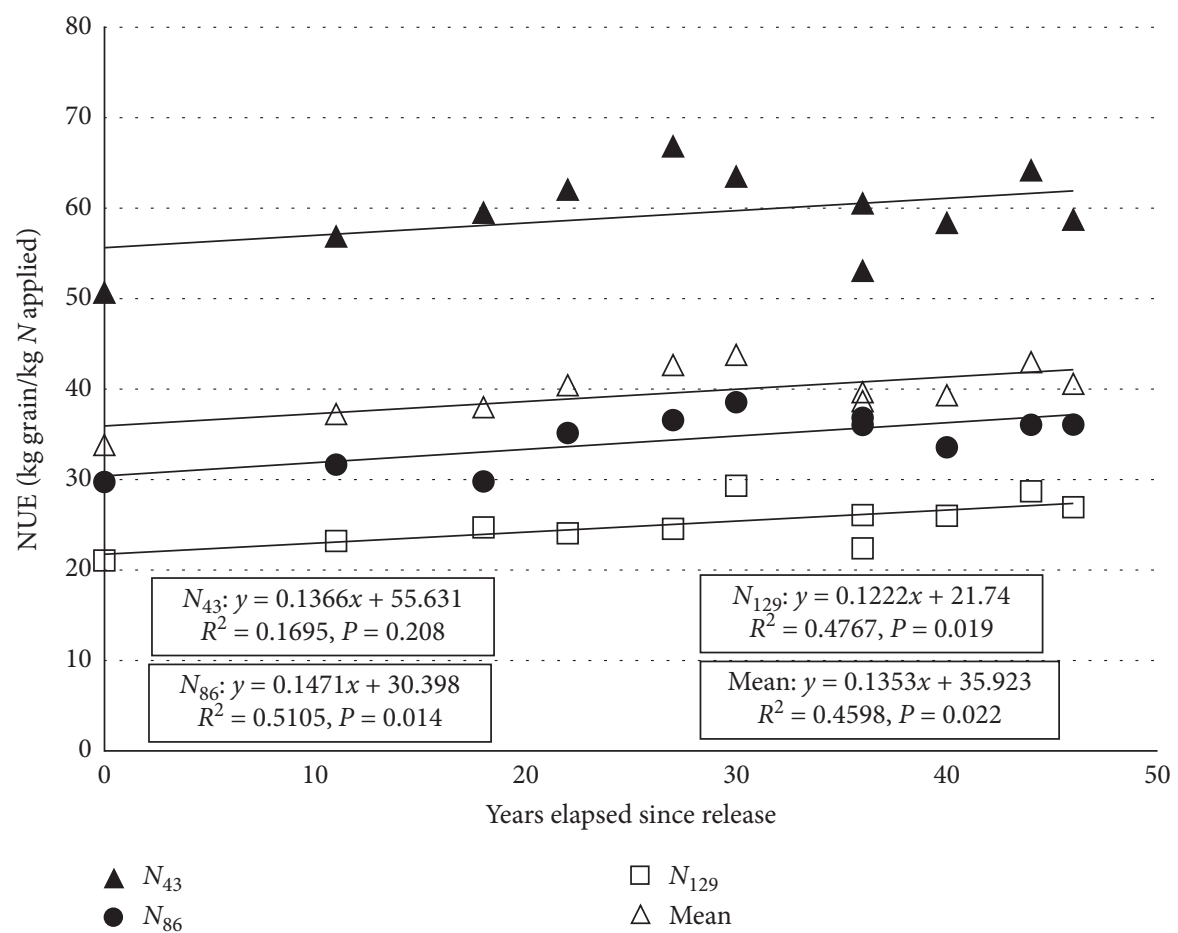

FIGURE 5: Relationship of NUE of 11 bread wheat cultivars released between 1960 and 2006 and grown at different N levels for two seasons (2006/07 and 2007/08) with the time elapsed since their year of release.

as Bohaine, Argine, and Condor showed significantly higher NHI across all N levels, whereas the tall cultivars (Beladi and Tagana) recorded the lowest NHI.
The grain yield produced from a unit of above ground plant $\mathrm{N}$ uptake, i.e., nitrogen utilization efficiency, NUTE, was significantly reduced with each increase in $\mathrm{N}$ rate. 
Across all $\mathrm{N}$ levels, the 12 wheat cultivars significantly varied in NUTE. With the exception of few modern cultivars (e.g., Argine and Tagana), NUTE was always higher in the semidwarf cultivars such as Debeira, Wadi Elneel, Khalifa, and Elnielain compared to the old tall cultivars. The aforementioned results showed that modern semidwarf cultivars are more efficient in utilizing the applied $\mathrm{N}$ than the old tall cultivars. The variability of modern cultivars' response to NUE has been attributed mainly to NUTE [1]. The differential response of cultivars with different $\mathrm{N}$ supply levels, regarding the NUTE, is important when defining the management and choosing the cultivar [32].

\subsection{Genetic Gain in Grain Yield under Different Nitrogen} Levels. Different rates of genetic gains were found under different $\mathrm{N}$ levels. The result of the genetic gain at $\mathrm{N}_{86}$ and $\mathrm{N}_{129}$ showed clearly that selection of the genotypes under these $\mathrm{N}$ levels reflected in the progress made in grain yield. Under different $\mathrm{N}$ levels, different rates of genetic gains were obtained. Ortiz-Monasterio et al. [12] reported that the genetic gains in grain yield at no or low $\mathrm{N}$ levels ( 0 and $75 \mathrm{~kg}$ of N/ha) were 32 and $43 \mathrm{~kg} / \mathrm{ha} /$ year, respectively, whereas at high $\mathrm{N}$ levels (150 and $300 \mathrm{~kg}$ of N/ha) the genetic gains were 59 and $89 \mathrm{~kg} / \mathrm{ha} / \mathrm{year}$, respectively. Our results under the four $\mathrm{N}$ levels did not follow exactly the same trend especially under $\mathrm{N}_{0}$ and $\mathrm{N}_{43}$ treatments, suggesting that the progress made in grain yield was affected by the conditions under which the selection of the cultivars has been made. Under the low $\mathrm{N}$ levels, old and modern cultivars responded almost similarly and no significant progress has been found. The significant positive trends at $\mathrm{N}_{86}$ and $\mathrm{N}_{129}$ showed that addition of $\mathrm{N}$ fertilizer was more beneficial to the modern cultivar than the old ones. It has been suggested that in order to identify the most efficient type for $\mathrm{N}$ use, the breeders need to test their material in low as well as high $\mathrm{N}$ environments [33]. On the other hand, similar genetic progress was reported at both high and low $\mathrm{N}$ treatments for 195 European winter wheat varieties [23]. However, direct selection at low $\mathrm{N}$ condition was recommended when the low $\mathrm{N}$ treatment is targeted.

Regressing the grain yield at $\mathrm{N}_{86}$ in the two seasons against the year of release, the annual rate of increase in grain yield was $12.65 \mathrm{~kg} \mathrm{ha}^{-1}$ year $^{-1}$. This genetic gain in grain yield is comparable with most of the reports in many countries such as Argentina [34], Canada [35], UK [36], and USA [37]. Higher rates of increase were reported under some favorable environments such as Mexico [12, 38, 39] and the United Kingdom [40]. On the other hand, lower rates were reported in Australia [41] and India [42]. It has been reported that increasing grain yield under stressed environments is a difficult task when compared with favorable environments [43]. This is true with the conditions of Sudan, where the major wheat growing areas experience high temperature during most parts of the crop cycle (Figure 1). Despite this, a reasonable level of improvement was achieved. However, when the period from 1960 to 1990 was considered, the genetic gains in grain yield at different $\mathrm{N}$ levels were higher. For instance, the genetic gain for the mean grain yield across all $\mathrm{N}$ levels was estimated to be $20.67 \mathrm{~kg} \mathrm{ha}^{-1}$ year $^{-1}$ (Figure 4). At $\mathrm{N}_{86}$ (the recommended $\mathrm{N}$ dose for wheat production in Sudan), the genetic gain was $24.5 \mathrm{~kg} \mathrm{ha}^{-1}$ year $^{-1}$, a figure which is closer to what has been reported earlier under the similar $\mathrm{N}$ level [25]. This showed that the rate of the genetic gain was slowed down in the recent years. The decelerated rate of genetic gain in grain yield has been reported elsewhere without being plateaued $[38,44]$. Noticeably, significant genetic gain was achieved during the period 1960 to 1990 under the low $\mathrm{N}$ level of $\mathrm{N}_{43}\left(21.14 \mathrm{~kg} \mathrm{ha}^{-1}\right.$ year $\left.^{-1}, R^{2}=0.924, P=0.002\right)$ (Figure 4).

4.3. Genetic Gain in NUE under Different Nitrogen Levels. The genetic gain in NUE under different nitrogen levels showed more or less similar trends of that of the grain yield. Although it has been observed that at the three $\mathrm{N}$ levels, the recently released semidwarf cultivars exhibited relatively higher NUEs compared to the old and tall ones (Beladi and Giza), the trend was stronger at higher $\mathrm{N}$ levels. This might reflect the effect of selecting the new varieties under high $\mathrm{N}$ level (mainly under $\mathrm{N}_{86}$ ). For further improvement in NUE, it would be useful to enrich the genetic variation and test and select genotypes at early stages under different $\mathrm{N}$ doses especially low levels. Ortiz-Monasterio et al. [12] measured the genetic progress in grain yield and NUE, particularly uptake efficiency (UPE) and utilization efficiency (UTE) using tall vs semidwarf wheat cultivars and reported that the progress in NUE resulted in the improvement of both UPE and UTE. Significant enhancement of NUE at both low and high $\mathrm{N}$ levels was reported [23], but more efficiently at low $\mathrm{N}$ level which demonstrated the higher yield stability of recent cultivars. Improvement in nitrogen use efficiency in the Great Plains' hard winter wheat germplasm in the period from 1960 to 2014 was found to be associated with significant trends of grain yield, grain $\mathrm{N}$ yield, nitrogen harvest index, nitrogen uptake efficiency, and postanthesis nitrogen uptake with year of release [24].

It is concluded that genotypes differentially responded to $\mathrm{N}$ levels in terms of various traits suggesting the existence of some level of variation in NUE among the studied genotypes. The set of released cultivars used in this study demonstrated that breeders improved grain yield and NUE over 46 years of crop improvement under the heat stress conditions of Sudan although the rate of increase in grain yield has been slowed down in recent years. The results also indicate that the best grain yields could be achieved when modern cultivars are used even under limited $\mathrm{N}$ levels. The selection of the cultivars under the optimum and high $\mathrm{N}$ conditions resulted in the genetic gain in grain yield under these conditions but not under no or low $\mathrm{N}$ doses. Therefore, for better improvement in NUE, simultaneous testing of wheat genotypes under different $\mathrm{N}$ levels would be useful especially under low doses. Due to the slowdown in genetic gain reported in recent years, new integrated approaches would be needed for further improvement including broadening the genetic base for abiotic stress tolerance especially in the light of the ensuing climate change. 


\section{Data Availability}

The data used to support the findings of this study are available from the corresponding author upon request.

\section{Conflicts of Interest}

The authors declare that they have no conflicts of interest.

\section{References}

[1] P. B. Barraclough, J. R. Howarth, J. Jones et al., "Nitrogen efficiency of wheat: genotypic and environmental variation and prospects for improvement," European Journal of Agronomy, vol. 33, no. 1, pp. 1-11, 2010.

[2] F. Cormier, J. Foulkes, B. Hirel, D. Gouache, Y. MoënneLoccoz, and J. Le Gouis, "Breeding for increased nitrogen-use efficiency: a review for wheat (T. aestivum L.)," Plant Breeding, vol. 135 , no. 3 , pp. $255-278,2016$.

[3] M. J. Foulkes, M. J. Hawkesford, P. B. Barraclough et al., "Identifying traits to improve the nitrogen economy of wheat: recent advances and future prospects," Field Crops Research, vol. 114, no. 3, pp. 329-342, 2009.

[4] O. Gaju, V. Allard, P. Martre et al., "Identification of traits to improve the nitrogen-use efficiency of wheat genotypes," Field Crops Research, vol. 123, no. 2, pp. 139-152, 2011.

[5] B. Hirel, J. Le Gouis, B. Ney, and A. Gallais, "The challenge of improving nitrogen use efficiency in crop plants: towards a more central role for genetic variability and quantitative genetics within integrated approaches," Journal of Experimental Botany, vol. 58, no. 9, pp. 2369-2387, 2007.

[6] M. J. Hawkesford, "Reducing the reliance on nitrogen fertilizer for wheat production," Journal of Cereal Science, vol. 59, no. 3, pp. 276-283, 2014.

[7] S. Liu, X. Li, D. H. Larsen, X. Zhu, F. Song, and F. Liu, "Drought priming at vegetative growth stage enhances nitrogen-use efficiency under post-anthesis drought and heat stress in wheat," Journal of Agronomy and Crop Science, vol. 203, no. 1, pp. 29-40, 2017.

[8] G. Guarda, S. Padovan, and G. Delogu, "Grain yield, nitrogenuse efficiency and baking quality of old and modern Italian bread-wheat cultivars grown at different nitrogen levels," European Journal of Agronomy, vol. 21, no. 2, pp. 181-192, 2004.

[9] J. Le Gouis, D. Béghin, E. Heumez, and P. Pluchard, "Genetic differences for nitrogen uptake and nitrogen utilisation efficiencies in winter wheat," European Journal of Agronomy, vol. 12, no. 3-4, pp. 163-173, 2000.

[10] M. Baric, H. Sarcevic, S. Keresa, I. Habus Jercic, and I. Rukavina, "Genotypic differences for nitrogen use efficiency in winter wheat (Triticum aestivum L.)," Cereal Research Communications, vol. 35, no. 2, pp. 213-216, 2007.

[11] J. I. Ortiz-Monasterio, G. G. B. Manske, and M. P. Van Ginkel, "Nitrogen and phosphorus use efficiency," in Application of Physiology in Wheat Breeding, M. P. Reynolds, J. I. OrtizMonasterio, and A. McNab, Eds., pp. 200-208, CIMMYT, Mexico City, Mexico, 2001.

[12] R. J. I. Ortiz-Monasterio, K. D. Sayre, S. Rajaram, and M. McMahon, "Genetic progress in wheat yield and nitrogen use efficiency under four nitrogen rates," Crop Science, vol. 37, no. 3, pp. 898-904, 1997.

[13] J. Le Gouis and P. Pluchard, "Genetic variation for nitrogen use efficiency in winter wheat (Triticum aestivum L.)," Euphytica, vol. 92, no. 1-2, pp. 221-224, 1996.
[14] E. Mansour, A. M. A. Merwad, M. A. T. Yasin, M. I. E. AbdulHamid, E. E. A. El-Sobky, and H. F. Oraby, "Nitrogen use efficiency in spring wheat: genotypic variation and grain yield response under sandy soil conditions," The Journal of Agricultural Science, vol. 155, no. 9, pp. 1407-1423, 2017.

[15] F. K. Kanampiu, W. R. Raun, and G. V. Johnson, "Effect of nitrogen rate on plant nitrogen loss in winter wheat varieties1," Journal of Plant Nutrition, vol. 20, no. 2-3, pp. 389-404, 1997.

[16] I. S. A. Tahir and N. Nakata, "Remobilization of nitrogen and carbohydrate from stems of bread wheat in response to heat stress during grain filling," Journal of Agronomy and Crop Science, vol. 191, no. 2, pp. 106-115, 2005.

[17] Z. I. Ali, S. E. Dawelbeit, and A. A. Salih, "Effect of water stress and nitrogen application on grain yield of wheat," in Proceedings of the Meetings of the National Crop Husbandry Committee, pp. 155-162, Wad Medani, Sudan, 2005.

[18] E. M. E. Elbashier, I. S. A. Tahir, A. S. I. Saad, and M. A. S. Ibrahim, "Wheat genotypic variability in utilizing nitrogen fertilizer for a cooler canopy under a heat-stressed irrigated environment," African Journal of Agricultural Research, vol. 7, no. 3, pp. 385-392, 2012.

[19] I. Amani, R. A. Fischer, and M. P. Reynolds, "Canopy temperature depression association with yield of irrigated spring wheat cultivars in a hot climate," Journal of Agronomy and Crop Science, vol. 176, no. 2, pp. 119-129, 1996.

[20] B. W. Hütsch, D. Jahn, and S. Schubert, "Grain yield of wheat (Triticum aestivum L.) under long-term heat stress is sinklimited with stronger inhibition of kernel setting than grain filling," Journal of Agronomy and Crop Science, vol. 205, no. 1, pp. 22-32, 2019.

[21] M. P. Reynolds, R. P. Singh, A. Ibrahim, O. A. A. Ageeb, A. Larqué-Saavedra, and J. S. Quick, "Evaluating physiological traits to complement empirical selection for wheat in warm environments," Euphytica, vol. 100, no. 1/3, pp. 85-94, 1998.

[22] I. S. A. Tahir, A. B. Elahmadi, O. S. Abdalla, A. S. Ibrahim, O. E. Mohammed, and N. Nakata, "Potential selection criteria for yield of bread wheat undernearly nad late heat stresses in a dry irrigated environment," Wheat Information Service, vol. 99, pp. 35-40, 2005.

[23] F. Cormier, S. Faure, P. Dubreuil et al., "A multi-environmental study of recent breeding progress on nitrogen use efficiency in wheat (Triticum aestivum L.)," Theoretical and Applied Genetics, vol. 126, no. 12, pp. 3035-3048, 2013.

[24] M. J. Guttieri, K. Frels, T. Regassa, B. M. Waters, and P. S. Baenziger, "Variation for nitrogen use efficiency traits in current and historical great plains hard winter wheat," Euphytica, vol. 213, no. 4, 2017.

[25] I. S. A. Tahir, A. B. Elahmedi, A. S. Ibrahim, and O. S. Abdalla, "Genetic improvement in grain yield and associated changes in traits of bread wheat cultivars in the Sudan," in The Eleventh Regional Wheat Workshop for Eastern, Central and Southern Africa, pp. 60-66, CIMMYT, Addis Ababa, Ethiopia, 2000.

[26] J. M. Bremner and C. S. Mulvaney, "Nitrogen-total," in Methods of Soil Analysis. Part 2. Chemical and Microbiological Properties, D. R. Page, A. L. Miller, and R. H. Kenney, Eds., pp. 595-624, Soil Science Society of America, Madison, Wisconsin, 1982.

[27] J. K. Ladha, H. Pathak, T. J. Krupnik, J. Six, and C. Van Kessel, "Efficiency of fertilizer nitrogen in cereal production: retrospects and prospects," Advances in Agronomy, vol. 87, no. 5, pp. 85-156, 2005.

[28] C. Noulas, P. Stamp, A. Soldati, and M. Liedgens, "Nitrogen use efficiency of spring wheat genotypes under field and 
lysimeter conditions," Journal of Agronomy and Crop Science, vol. 190, no. 2, pp. 111-118, 2004.

[29] M. Brancourt-Hulmel, E. Heumez, P. Pluchard et al., "Indirect versus direct selection of winter wheat for low-input or highinput levels," Crop Science, vol. 45, no. 4, pp. 1427-1431, 2005.

[30] B. Gorjanović, M. Brdar-Jokanović, and M. Kraljević-Balalić, "Phenotypic variability of bread wheat genotypes for nitrogen harvest index," Genetika, vol. 43, no. 2, pp. 419-426, 2007.

[31] P. B. Barraclough, R. Lopez-Bellido, and M. J. Hawkesford, "Genotypic variation in the uptake, partitioning and remobilisation of nitrogen during grain-filling in wheat," Field Crops Research, vol. 156, pp. 242-248, 2014.

[32] M. H. Todeschini, A. S. Milioli, D. M. Trevizan et al., "Nitrogen use efficiency in modern wheat cultivars," Bragantia, vol. 75, no. 3, pp. 351-361, 2016.

[33] K. Hitz, A. J. Clark, and D. A. Van Sanford, "Identifying nitrogen-use efficient soft red winter wheat lines in high and low nitrogen environments," Field Crops Research, vol. 200, pp. 1-9, 2017.

[34] G. A. Slafer, F. H. Andrade, and S. E. Feingold, "Genetic improvement of bread wheat (Triticum aestivum L.) in Argentina: relationships between nitrogen and dry matter," Euphytica, vol. 50, no. 1, pp. 63-71, 1990.

[35] P. Hucl and R. J. Baker, "A study of ancestral and modern Canadian spring wheats," Canadian Journal of Plant Science, vol. 67, no. 1, pp. 87-97, 1987.

[36] V. J. Shearman, R. Sylvester-Bradley, R. K. Scott, and M. J. Foulkes, "Physiological processes associated with wheat yield progress in the UK," Crop Science, vol. 45, no. 1, pp. 175-185, 2005.

[37] E. Donmez, R. G. Sears, J. P. Shroyer, and G. M. Paulsen, "Genetic gain in yield attributes of winter wheat in the great plains," Crop Science, vol. 41, no. 5, pp. 1412-1419, 2001.

[38] K. A. B. Aisawi, M. P. Reynolds, R. P. Singh, and M. J. Foulkes, "The physiological basis of the genetic progress in yield potential of CIMMYT spring wheat cultivars from 1966 to 2009," Crop Science, vol. 55, no. 4, pp. 1749-1764, 2015.

[39] K. D. Sayre, S. Rajaram, and R. A. Fischer, "Yield potential progress in short bread wheats in northwest Mexico," Crop Science, vol. 37, no. 1, pp. 36-42, 1997.

[40] R. B. Austin, "Yield of wheat in the United Kingdom," Crop Science, vol. 39, no. 6, p. 1604, 2010.

[41] M. Perry and M. D’Antuono, "Corrigendum-yield improvement and associated characteristics of some Australian spring wheat cultivars introduced between 1860 and 1982," Australian Journal of Agricultural Research, vol. 40, no. 3, pp. 457-472, 1989.

[42] S. K. Sinha, P. K. Aggarwal, G. S. Chaturvedi, K. R. Koundal, and R. Khanna-Chopra, "A comparison of physiological and yield characters in old and new wheat varieties," The Journal of Agricultural Science, vol. 97, no. 1, pp. 233-236, 1981.

[43] G. A. Slafer, E. H. Satorre, and F. H. Andrade, "Increases in grain yield in bread wheat from breeding and associated physiological changes," in Genetic Improvement of Field Crops: Current Status and Development, G. A. Slafer, Ed., pp. 1-68, Marcel Dekker, New York, NY, USA, 1994.

[44] B. M. Flohr, J. R. Hunt, J. A. Kirkegaard, J. R. Evans, A. Swan, and B. Rheinheimer, "Genetic gains in NSW wheat cultivars from 1901 to 2014 as revealed from synchronous flowering during the optimum period," European Journal of Agronomy, vol. 98, pp. 1-13, 2018. 